\title{
Evaluation of the cytotoxic effect of Ly2109761 on HeLa cells using the xCELLigence RTCA system
}

\author{
İDİ ÇETIN and MEHMET R. TOPÇUL \\ Department of Biology, Faculty of Science, Istanbul University, Istanbul 34459, Turkey
}

Received October 24, 2017; Accepted August 15, 2018

DOI: $10.3892 / \mathrm{ol} .2018 .9556$

\begin{abstract}
In the present study, the in vitro cytotoxic effect of a novel transforming growth factor- $\beta$ receptor inhibitor, LY2109761, was investigated in the human cervix carcinoma HeLa cell lines. For the purpose of the present study, cell index values obtained using the xCELLigence Real-Time Cell Analysis DP instrument, and mitotic, labelling and apoptotic index analysis were used. The results of the present study indicated that LY2109761 affected the cytoskeleton of HeLa cells, decreased the mitotic and labelling index values of the HeLa cell line, and increased the apoptotic index values. Significant differences were observed between the control group which was not treated with LY2109761 and the experimental groups, which were treated with LY2109761 $(\mathrm{P}<0.01)$. The results of the present study suggest that LY2109761 may serve as a promising treatment option for cervix carcinoma.
\end{abstract}

\section{Introduction}

Transforming growth factor (TGF)- $\beta$ receptors, a family of polypeptides, have been reported to serve a role in regulating various biological functions, including proliferation, migration, survival, angiogenesis, immune-surveillance, and embryonic stem cell maintenance and differentiation (1). It has been demonstrated that a dysregulation in the signalling of the aforementioned factors is associated with tumour development and metastasis (2). It has been reported that the TGF- $\beta$ pathway possesses anti- and pro-tumour activities $(3,4)$, promoting cell cycle arrest and apoptosis at the beginning of tumorigenesis (5-7). In contrast, the TGF- $\beta$ pathway has been reported to promote cancer cell motility, invasion, epithelial-to-mesenchymal transition and cell stemness following progression to

Correspondence to: Dr İdil Çetin, Department of Biology, Faculty of Science, Istanbul University, Vezneciler Street, Istanbul 34459, Turkey

E-mail: idil.cetin@istanbul.edu.tr

Key words: transforming growth factor- $\beta$ receptor inhibitor, HeLa cell culture, xCELLigence Real-Time Cell Analysis DP instrument more advanced tumour stages (5-7). Therefore, the TGF- $\beta$ pathway has been demonstrated to serve an important role in tumour progression and metastasis. The aforementioned phenomenon is known as the first 'TGF- $\beta$ paradox' (8). The TGF- $\beta$ signalling pathway has attracted increasing attention over the past three decades and has become a popular drug development target for oncologists (9). As a result of the wide variety of effects of TGF- $\beta$ on tumorigenesis, blockade of TGF- $\beta$ and its signalling pathway provides multiple therapeutic opportunities. Anti-TGF- $\beta$ compounds have been developed, and through preclinical studies and clinical trials, their efficacies have been demonstrated (10). Therefore, it has been suggested that TGF- $\beta$ signalling inhibition may serve as a promising strategy for regulating tumour progression, including metastasis (10).

\section{Materials and methods}

Cell culture. HeLa cells were obtained from the American Type Culture Collection (Manassas, VA, USA). The cell lines were cultured in Dulbecco's modified Eagle's medium-199 (Sigma-Aldrich; Merck KGaA, Darmstadt, Germany) containing 10\% (v/v) fetal bovine serum (Gibco; Thermo Fisher Scientific, Inc., Waltham, MA, USA) and 1\% penicillin-streptomycin. Cells were cultured at $37^{\circ} \mathrm{C}$ with $5 \% \mathrm{CO}_{2}$. HeLa cells were treated with 25,50 and $75 \mu \mathrm{M}$ of LY2109761 between 0 and $72 \mathrm{~h}$ and subsequently analyzed and evaluated.

TGF- $\beta$ receptor inhibitor (LY2109761) concentrations. LY2109761 (Tocris Bioscience, Bristol, UK) concentrations used. A total of $1 \mathrm{mM}$ stock solution was prepared, and from that three different concentrations of 25,50 and $75 \mu \mathrm{M}$ of LY2109761 were prepared.

\section{Measurement of cytotoxicity}

Cell index $(\mathrm{CI})$. Experiments were performed using the $\mathrm{xCEL}-$ Ligence Real-Time Cell Analysis (RTCA) DP instrument (Roche Diagnostics GmbH, Mannheim, Germany) at $37^{\circ} \mathrm{C}$ with $5 \% \mathrm{CO}_{2}$. In order to measure the cytotoxic response of HeLa cells in real-time, cells were seeded on gold microelectrodes embedded at the bottom of 16 well microplates (E-plates; Roche Diagnostics, Basel, Switzerland) at a density of $6.0 \times 10^{3}$ cells/well for HeLa cells. The impedance was recorded at $15 \mathrm{~min}$ intervals. 25,50 and $75 \mu \mathrm{M}$ of LY2109761 
were added to the culture $20 \mathrm{~h}$ subsequent to seeding. All incubations were performed at a volume of $200 \mu 1$ between 0 and $72 \mathrm{~h} . \mathrm{IC}_{50}$ values were evaluated by the RTCA-DP software (Roche Diagnostics $\mathrm{GmbH}$ ) using the sigmoidal dose-response curves.

Mitotic index (MI). HeLa cells were plated on coverslips at a density of $2 \times 10^{4}$ cells/well and treated with Dulbecco's modified Eagle's medium-199 medium (Sigma-Aldrich; Merck $\mathrm{KGaA}$ ) containing $10 \%(\mathrm{v} / \mathrm{v})$ fetal bovine serum (Gibco; Thermo Fisher Scientific, Inc.) and $1 \%$ penicillin-streptomycin for the control group and with LY2109761 for the experimental group between 0 and $72 \mathrm{~h}$. The cells were subsequently fixed using Carnoy fixative at a dilution of 3:1 ethanol and acetic acid at room temperature for $10 \mathrm{~min}$. The MI was determined using the Feulgen method, where cells were treated with $1 \mathrm{~N}$ of $\mathrm{HCl}$ at room temperature for $1 \mathrm{~min}$ and then hydrolized with $1 \mathrm{~N}$ of $\mathrm{HCl}$ for $10.5 \mathrm{~min}$ at $60^{\circ} \mathrm{C}$. Slides were subsequently treated with Feulgen for 1 hour and were rinsed for $3 \mathrm{~min}$ in distilled water. Cells were subsequently stained with $10 \%$ Giemsa stain solution (pH 6.8) at room temperature for $3 \mathrm{~min}$ and washed twice in PBS. Finally, the MI was evaluated by counting cells with a light microscope (magnification, x100) in different phases of mitosis for each tested inhibitor concentration and control, and a minimum of $3.0 \times 10^{3}-3.5 \times 10^{3}$ cells were examined from each slide for MI calculations. The MI percentage (\%) was scored using the following formula: (Cells in mitotic phases/total cell number) x100.

${ }^{3} \mathrm{H}$-thymidine labelling index (LI) analysis. ${ }^{3} \mathrm{H}$-thymidine labelling index analysis is used to determine cells in the $\mathrm{S}$ phase. For the ${ }^{3} \mathrm{H}$-thymidine LI analysis, a medium containing $1 \mu \mathrm{Ci} / \mathrm{ml}{ }^{3} \mathrm{H}$-thymidine was applied to the control and test groups for $20 \mathrm{~min}$ at room temperature. Subsequent to labelling, the cells were fixed with Carnoy's fixative (3:1, ethanol and acetic acid) at room temperature for $10 \mathrm{~min}$ and the remaining radioactive material was washed twice with $2 \%$ perchloric acid at $4^{\circ} \mathrm{C}$ for $30 \mathrm{~min}$. Coverslips were coated with K.2 gel emulsion (Ilford Photo, Cheshire, UK). Following exposure time autoradiograms were bathed with D-19 b developer (Kodak, Rochester, NY, USA) and Fixaj B (Kodak). The cells were subsequently stained with Giemsa at room temperature for $3 \mathrm{~min}$. Cells were considered ${ }^{3} \mathrm{H}$-thymidine labelled when they contained a minimum of five discrete silver grains. Over $3 \times 10^{3}$ cells from each coverslip were examined with light microscope (magnification, $x 100$ ). The LI percentage was scored using the following formula: (Cells in synthesis phase/total cell number) x100.

Apoptotic index (AI). Cells were seeded in 6-well plates $\left(3 \times 10^{4}\right.$ cells $\left./ \mathrm{ml}\right)$ and were trypsinized with $0.25 \%$ Tyripsin-EDTA (Gibco; Thermo Fisher Scientific, Inc.) $\sim 37^{\circ} \mathrm{C}$ for $3 \mathrm{~min}$ and were fixed at room temperature using 1:1 methanol and PBS, respectively, and pure methanol for $3 \mathrm{~min}$. Following fixation, the nucleus of HeLa cells was stained using $1 \mu \mathrm{g} / \mathrm{ml}$ of DAPI labelling solution (Sigma-Aldrich; Merck KGaA) for $20 \mathrm{~min}$ at room temperature and washed once with PBS. Cells were analysed with fluorescent microscopy (magnification, $\mathrm{x} 1,000$ ). The AI percentage was scored using the following formula: (Apoptotic cell number/total cell number) $\mathrm{x} 100$.

Statistical analysis. All experiments were repeated three times. Statistical analysis was performed using SPSS statistics 17.0 software (SPSS, Inc., Chicago, IL, USA). Statistical analysis of AI, LI and MI was performed using a two-tailed Student's $\mathrm{t}$-test, in order to determine significance. All values are expressed as the mean \pm standard deviation. Values obtained from all experimental groups were analysed using one-way analysis of variance with Dunnett's multiple comparison post hoc test. $\mathrm{P}<0.01$ was considered to indicate a statistically significant difference.

\section{Results}

LY2109761 affects the proliferation and cytoskeleton of HeLa cells. CI values obtained from xCelligence RTCA system indicated that LY2109761 concentrations had an evident antiproliferative effect on HeLa cell line. The values also indicated that all LY2109761 concentrations affected the cytoskeleton of HeLa cells (Fig. 1). As indicated in Fig. 2, the $\mathrm{IC}_{50}$ value for HeLa cells was determined as $39 \mu \mathrm{M}$ LY2109761, according to the data analysis performed using xCelligence DP software. Therefore, $39 \mu \mathrm{M}$ LY2109761 was used in the subsequent experiments performed in the present study.

LY2109761 decreases the rate of mitotic cells in HeLa cell culture. The MI values at a LY2109761 concentration of $39 \mu \mathrm{M}$ are presented in Table I and Fig. 3. According to the presented data, the MI values of HeLa cells treated with LY2109761 started to exhibit a significant decline at $24 \mathrm{~h}(\mathrm{P}<0.01)$, and continued to significantly decline $(\mathrm{P}<0.01)$ for up to $72 \mathrm{~h}$ compared with the control. The decrease in the mitosis parameter at these rates is of considerable value in terms of cancer prognosis. A decrease in mitotic rate of cells may assist to prevent the progression of the cancer, allowing the treatment to be carried out successfully.

LY2109761 reduces the proportion of cells in the synthesis phase in HeLa cell cultures. Table II and Fig. 4 present the LI values. The LI parameter, which determines the ratio of cells in the synthesis phase, was evaluated. The decrease in the rate of labelling, particularly at $72 \mathrm{~h}$, indicated that the cells were blocked at the synthesis phase. The decrease in the number of HeLa cells following exposure to $39 \mu \mathrm{M}$ LY2109761 concentration was statistically significant compared with control $(\mathrm{P}<0.01)$.

LY2109761 increases the rate of apoptotic cells in HeLa cell culture. The AI values of HeLa cells treated with $39 \mu \mathrm{M}$ LY2109761 are presented in Table III and Fig. 5. The significant increase in AI values indicated that HeLa cells activated the apoptotic death pathway $(\mathrm{P}<0.01)$, suggesting that they may serve an important role in cancer treatment and prognosis.

\section{Discussion}

In the present study, the cytotoxic effects of LY2109761 on HeLa cells were evaluated. The cell kinetic parameters used 


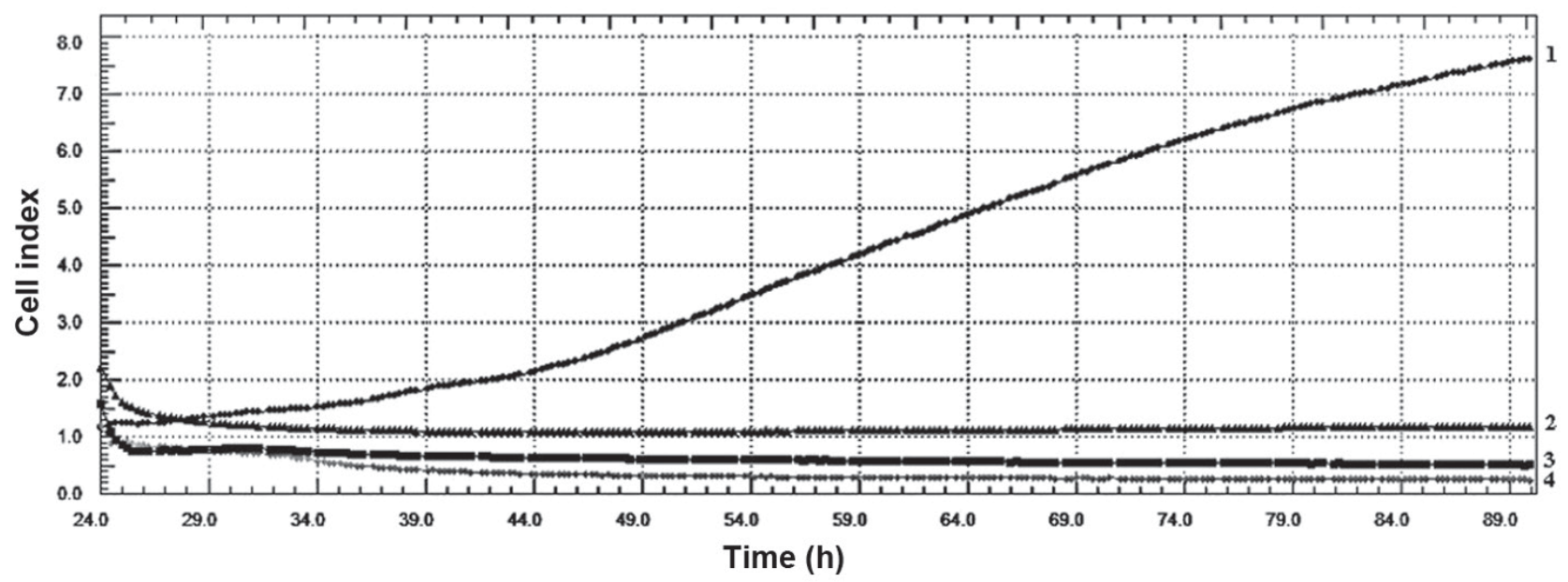

Figure 1. Cell index values of HeLa cells treated with 25,50 and $75 \mu \mathrm{M}$ of LY2109761. The values indicate that all LY2109761 concentrations had a significant cytoskeletal and antiproliferative effect on HeLa cell line. Line 1: Control; Line 2: $25 \mu \mathrm{M}$; Line 3:50 $\mu \mathrm{M}$; Line 4: $75 \mu \mathrm{M}$.

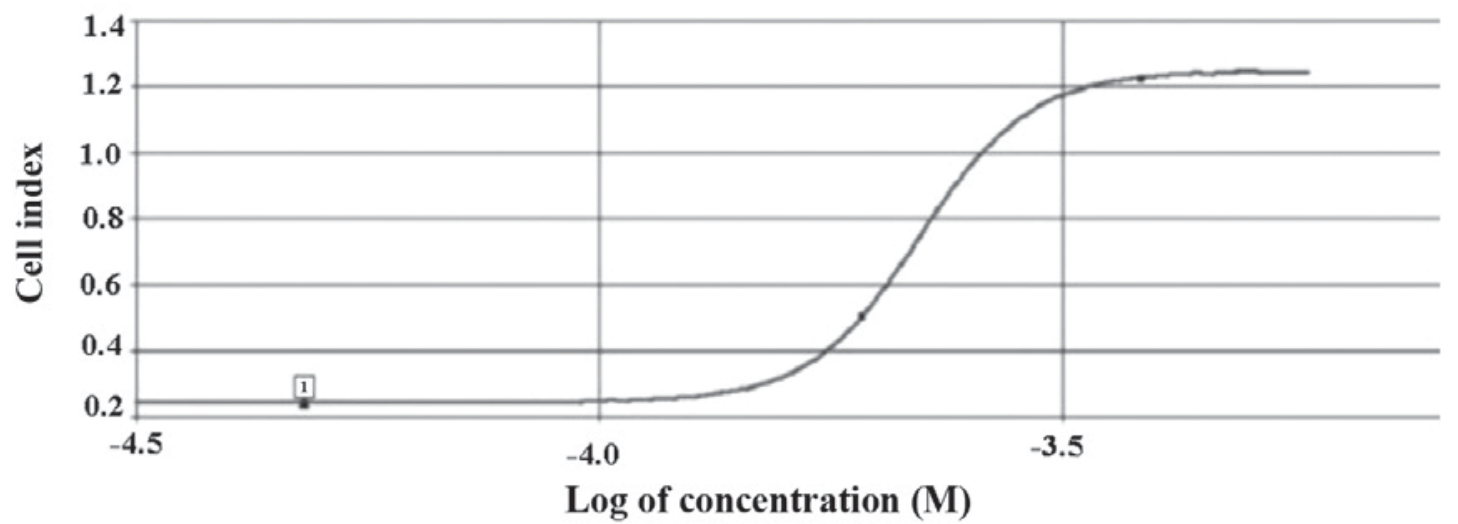

Figure 2. $\mathrm{IC}_{50}$ values obtained from the $\mathrm{xCelligence} \mathrm{real-time} \mathrm{cell} \mathrm{analysis} \mathrm{system.} 39 \mu \mathrm{M}$ of $\mathrm{LY} 2109761$ concentration was determined to be the $\mathrm{IC}_{50}$ value for HeLa cells.

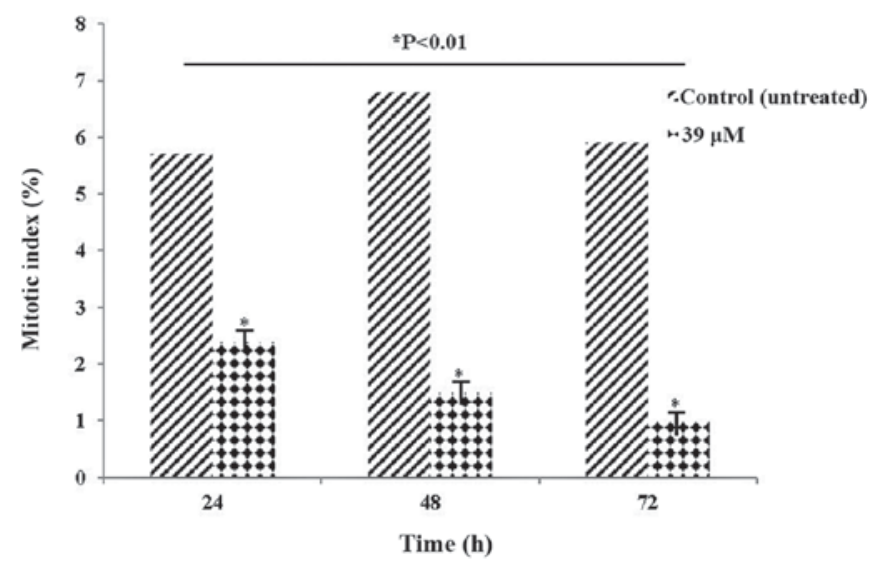

Figure 3. Mitotic index (\%) values of HeLa cells treated with $39 \mu \mathrm{M}$ LY2109761 for 24, 48 and $72 \mathrm{~h}$. LY2109761 started to exhibit a significant decline at $24 \mathrm{~h}$, and continued to significantly decrease for up to $72 \mathrm{~h}$ compared with the control. " $\mathrm{P}<0.01$ compared with the control.

in the present study demonstrated significant alterations to the CI, MI, LI and MI following treatment with LY2109761. The data of the present study indicate changes in proliferation at a cellular level, thus providing information on the effects of LY2109761 on cell activity. The function of TGF- $\beta$ in tumour metastasis has previously been demonstrated by researchers in a series of cancer models (11). TGF- $\beta$ has been reported to be a significant contributor to bone metastasis (12), and blockade of the TGF- $\beta$ signalling pathway with TGF- $\beta$ inhibitor LY2109761 has been demonstrated to inhibit connective tissue growth factor production and tumour growth (13).

In a study by Gao et al (14), LY2109761 was indicated to increase the apoptotic rate of cisplatin-resistant cells. The combination treatment of LY2109761 and cisplatin demonstrated an antiproliferative effect, in addition to inducing an increase in the apoptotic rate compared with the apoptotic rates following treatment with each drug separately. Furthermore, this combined treatment has been demonstrated to promote tumour regression in established parental and cisplatin-resistant ovarian cancer xenograft models. TGF- $\beta$ inhibition by various agents, including LY2109761, SD-208 and trabedersen, has been demonstrated to reduce pancreatic ductal adenocarcinoma cell invasion in vitro and metastasis in vivo (15-17).

LY2109761 has also been reported to exhibit anti-tumour activity against solid and haematological malignancies, and to suppress pancreatic cancer metastasis to the stomach (16). 
Table I. Mitotic index (\%) values of HeLa cells treated with $39 \mu \mathrm{M}$ of LY2109761 for 24,48 and $72 \mathrm{~h}$.

\begin{tabular}{llc}
\hline & \multicolumn{2}{c}{ Mitotic index (\%) } \\
\cline { 2 - 3 } Time (h) & Control & $39 \mu \mathrm{M}$ \\
\hline 24 & $5.7 \pm 0.03$ & $2.39 \pm 0.04^{\mathrm{a}}$ \\
48 & $6.8 \pm 0.02$ & $1.49 \pm 0.02^{\mathrm{a}}$ \\
72 & $5.9 \pm 0.04$ & $0.98 \pm 0.01^{\mathrm{a}}$ \\
\hline
\end{tabular}

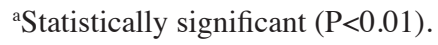

Table II. Labelling index (\%) values of HeLa cells treated with $39 \mu \mathrm{M}$ of LY2109761 for 24,48 and $72 \mathrm{~h}$.

\begin{tabular}{llc}
\hline \multirow{2}{*}{ Time (h) } & \multicolumn{2}{c}{ Labelling index (\%) } \\
\cline { 2 - 3 } & Control & $39 \mu \mathrm{M}$ \\
\hline 24 & $6.7 \pm 0.03$ & $3.42 \pm 0.06^{\mathrm{a}}$ \\
48 & $8.9 \pm 0.05$ & $2.26 \pm 0.04^{\mathrm{a}}$ \\
72 & $9.7 \pm 0.04$ & $1.18 \pm 0.01^{\mathrm{a}}$ \\
\hline
\end{tabular}

${ }^{a}$ Statistically significant $(\mathrm{P}<0.01)$.

Table III. Apoptotic index (\%) values of HeLa cells treated with $39 \mu \mathrm{M}$ of LY2109761 for 24, 48 and $72 \mathrm{~h}$.

\begin{tabular}{|c|c|c|}
\hline \multirow[b]{2}{*}{ Time (h) } & \multicolumn{2}{|c|}{ Apoptotic index (\%) } \\
\hline & Control & $39 \mu \mathrm{M}$ \\
\hline 24 & $3.26 \pm 0.03$ & $6.98 \pm 0.07^{\mathrm{a}}$ \\
\hline 48 & $3.48 \pm 0.02$ & $10.26 \pm 0.08^{\mathrm{a}}$ \\
\hline 72 & $4.12 \pm 0.06$ & $17.82 \pm 0.12^{\mathrm{a}}$ \\
\hline
\end{tabular}

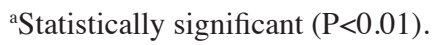

LY2109761 has been indicated to reduce tumour mass and increase the survival rate of orthotopic murine model of metastatic pancreatic cancer (16). In another study by Xu et al (18), LY2109761 was demonstrated to inhibit the survival of leukaemia cells and the amount of TGF- $\beta 1$ produced by bone marrow stromal cells that maintains chemotherapy resistance.

A limitation of the present study is that only tissue culture experiments were conducted. Animal experiments should be performed in future studies and the data should be evaluated to determine whether it is compatible with the present study.

The results of the present study indicated that LY2109761 affected the cytoskeleton of HeLa cells. In addition, while LY2109761 significantly reduced MI and LI values in the HeLa cell line, it increased AI values. Therefore, the results of the present study appear to be concordant with the aforementioned studies. As a result, when the alterations in AI,

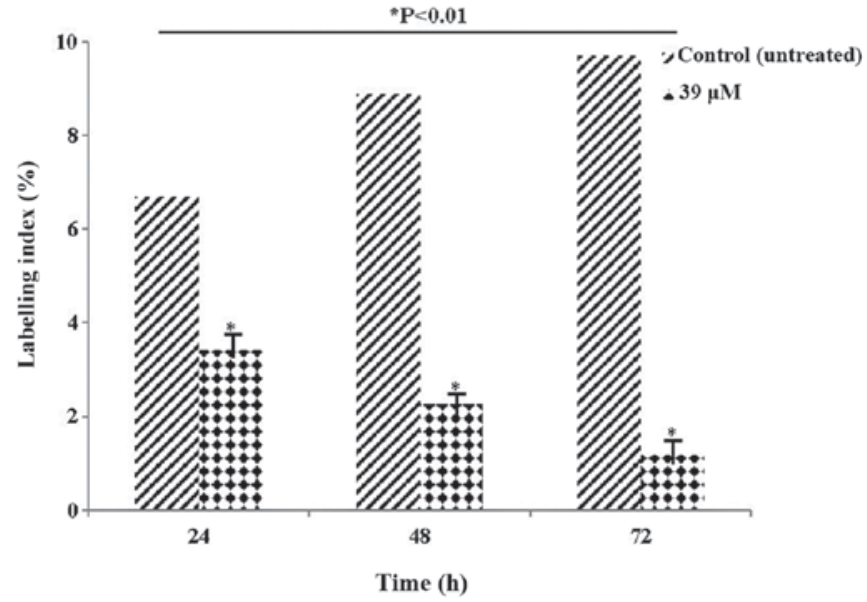

Figure 4. Labelling index (\%) values of HeLa cells treated with $39 \mu \mathrm{M}$ of LY2109761 for 24, 48 and $72 \mathrm{~h}$. The decrease in the rate of labelling, particularly at $72 \mathrm{~h}$, indicated that the cells were blocked at the synthesis phase. ${ }^{*} \mathrm{P}<0.01$ compared with the control.

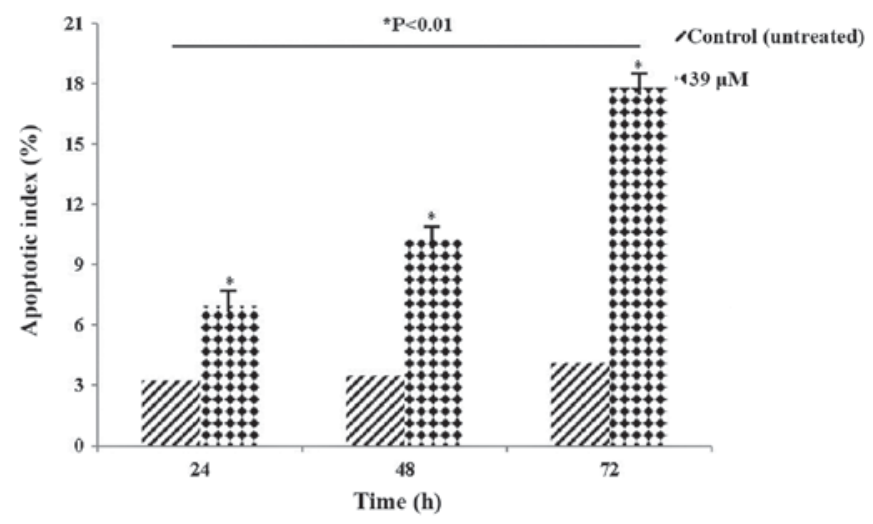

Figure 5. Apoptotic index (\%) values of HeLa cells treated with $39 \mu \mathrm{M}$ of LY2109761 for 24, 48 and $72 \mathrm{~h}(\mathrm{P}<0.01)$. The increases in apoptotic index data indicated that HeLa cells activated the apoptotic death pathway ${ }^{*} \mathrm{P}<0.01$ compared with the control.

CI, LI and MI values were examined, $39 \mu \mathrm{M}$ LY2109761 caused regression in proliferation. Changes at a cellular level suggest that this inhibitor may also regress cancer on a clinical level in human cervical carcinoma. For this reason, LY2109761 offers a promising treatment option for cervical carcinoma.

\section{Acknowledgements}

Not applicable.

\section{Funding}

The present study was supported by Scientific Research Projects Coordination Unit of Istanbul University (grant no, 49748 and 41832; Istanbul, Turkey).

\section{Availability of data and materials}

The datasets used and/or analyzed during the current study are available from the corresponding author on reasonable request. 


\section{Authors' contributions}

İÇ and MT designed the study. İÇ and MT performed the experiments. İÇ analyzed the data. Both authors have read and approved the final version of the manuscript.

\section{Ethics approval and consent to participate}

Not applicable.

\section{Patient consent for publication}

Not applicable.

\section{Competing interests}

The authors declare that they have no competing interests.

\section{References}

1. Derynck $R$ and Zhang YE: Smad-dependent and Smad-independent pathways in TGF-beta family signalling. Nature 425: 577-584, 2003

2. Neuzillet C, Tijeras-Raballand A, Cohenb R, Cros J, Faivre S, Raymond $\mathrm{E}$ and de Gramont A: Targeting the TGF $\beta$ pathway for cancer therapy. Pharmacol Ther 147: 22-31, 2015.

3. Inman GJ: Switching TGF $\beta$ from a tumour suppressor to a tumour promoter. Curr Opin Genet Dev 21: 93-99, 2011.

4. Principe DR, Doll JA, Bauer J, Jung B, Munshi HG, Bartholin L Pasche B, Lee C and Grippo PJ: TGF- $\beta$ : Duality of function between tumour prevention and carcinogenesis. J Natl Cancer Inst 106: djt369, 2014.

5. Jakowlew SB: Transforming growth factor-beta in cancer and metastasis. Cancer Metastasis Rev 25: 435-457, 2006.

6. Tian M, Neil JR and Schiemann WP: Transforming growth factor- $\beta$ and the hallmarks of cancer. Cell Signal 23: 951-962, 2011.

7. Drabsch Y and ten Dijke P: TGF- $\beta$ signalling and its role in cancer progression and metastasis. Cancer Metastasis Rev 31: $553-568,2012$
8. Wendt MK, Tian M and Schiemann WP: Deconstructing the mechanisms and consequences of TGF- $\beta$-induced EMT during cancer progression. Cell Tissue Res 347: 85-101, 2012.

9. Akhurst RJ and Hata A: Targeting the TGF $\beta$ signalling pathway in disease. Nat Rev Drug Discov 11: 790-811, 2012.

10. Yingling JM, Blanchard KL and Sawyer JS: Development of TGF-beta signalling inhibitors for cancer therapy. Nat Rev Drug Discov 3: 1011-1022, 2004.

11. Wiercinska E, Naber HP, Pardali E, van der Pluijm G, van Dam H and ten Dijke P: The TGF- $\beta /$ Smad pathway induces breast cancer cell invasion through the up-regulation of matrix metalloproteinase 2 and 9 in a spheroid invasion model system. Breast Cancer Res Treat 128: 657-666, 2011.

12. Kingsley LA, Fournier PG, Chirgwin JM and Guise TA: Molecular biology of bone metastasis. Mol Cancer Ther 6: 2609-2617, 2007.

13. Bennewith KL, Huang X, Ham CM, Graves EE, Erler JT, Kambham N, Feazell J, Yang GP, Koong A and Giaccia AJ: The role of tumor cell derived connective tissue growth factor (CTGF/CCN2) in pancreatic tumor growth. Cancer Res 69 775-784, 2009

14. Gao Y, Shan N, Zhao C, Wang Y, Xu F, Li J, Yu X, Gao L and Yi Z: LY2109761 enhances cisplatin antitumor activity in ovarian cancer cells. Int J Clin Exp Pathol 8: 4923-4932, 2015.

15. Gaspar NJ, Li L, Kapoun AM, Medicherla S, Reddy M, Li G, O'Young G, Quon D, Henson M, Damm DL, et al: Inhibition of transforming growth factor beta signaling reduces pancreatic adenocarcinoma growth and invasiveness. Mol Pharmacol 72: 152-161, 2007.

16. Melisi D, Ishiyama S, Sclabas GM, Fleming JB, Xia Q, Tortora G, Abbruzzese JL and Chiao PJ: LY2109761, a novel transforming growth factor beta receptor type I and type II dual inhibitor, as a therapeutic approach to suppressing pancreatic cancer metastasis. Mol Cancer Ther 7: 829-840, 2008.

17. Schlingensiepen KH, Jaschinski F, Lang SA, Moser C, Geissler EK, Schlitt HJ, Kielmanowicz M and Schneider A: Transforming growth factor-beta 2 gene silencing with trabedersen (AP 12009) in pancreatic cancer. Cancer Sci 102: 1193-1200, 2011

18. Xu Y, Tabe Y, Jin L, Watt J, McQueen T, Ohsaka A, Andreeff $\mathrm{M}$ and Konopleva M: TGF-beta receptor kinase inhibitor LY2109761 reverses the anti-apoptotic effects of TGF-betal in myelo-monocytic leukaemic cells co-cultured with stromal cells. Br J Haematol 142: 192-201, 2008. 